\title{
INFLUENCE OF GROWTH STIMULATOR MET ON MORPHO-PHYSIOLOGICAL TRAITS OF BUCKWHEAT
}

Jin Xiaomei, Liaoning Academy of Agricultural Sciences, Chinese People's Republic

The efficacy of application of MET at different concentrations on some morphological and physiological traits of buckwheat variety Yunchao-5 was studied. The results demonstrated efficacy of MET to reduce plant height and increase stem thickness. The experiments showed that the most efficient action was recorded in the variant with the MET concentration of $200 \mathrm{mg} / \mathrm{L}$, which substantially increased values of such traits as the grain number and 1000 seed weight. A gain in grain yield by $58.9 \%$ was also observed.

\section{Key words: buckwheat, MET, chlorophyll, plant height, stem thickness, physiology, yield capacity}

Introduction. Buckwheat is one of the major cereals in China. Buckwheat is highly digestible, nutritious and of good taste, and in terms of nutritional value and dietary qualities is a valuable food product. It has a high nutritional value because of its intrinsic ratio between essential amino acids in protein as well as because of certain medicinal properties [1].

Analysis of publications, pose the problem. Observation during buckwheat vegetation demonstrated that one week after MET treatment leaf color began to change from light-green to dark-green, and 10 days after treatment leaves were dense dark green. Leaf blade became thicker, and leaf edges were slightly curved [2]. Superoxide dismutase (SOD). is one of the most important enzymes that prevent free radical oxidation in plants. Together with catalase and other antioxidant enzymes, it protects the organism from constantly forming highly toxic oxygen radicals $[3,4]$. Superoxide dismutase catalyses dismutation of superoxide into oxygen and hydrogen peroxide. Thus, it plays an important role in antioxidant protection of virtually all cells that are one way or another are in contact with oxygen [5, 6].

The aim and tasks of the study. Investigation of effects of the growth regulator MET on buckwheat morpho-physiological traits and yield capacity. Determination of an optimum concentration to achieve the maximum economic benefit from application of MET.

Material and methods. The investigations were carried out in 2012-2013 at the Experimental Station of Heilongjiang Academy of Agricultural Sciences. Plot soil is leached black earth with humus content of $2.35 \%$, the stock of total nitrogen in topsoil is $0.12 \%$, mobile nitrogen $7.25 \mathrm{mg} / \mathrm{kg}$, mobile phosphorus - $183.7 \mathrm{mg} / \mathrm{kg}$.

Planting was carried out in open ground, upon sowing urea in the dose of $1.7 \mathrm{~g} / \mathrm{m}^{2}$ and superphosphate in the dose of $3.3 \mathrm{~g} / \mathrm{m}^{2}$ were introduced. During the flowering phase liquid fertilization with urea in the dose of $0.6 \mathrm{~g} / \mathrm{m}^{2}$ and superphosphate in the dose of $3.2 \mathrm{~g} / \mathrm{m}^{2}$ was carried out. The experiment included five variants with various concentrations of MET: 0, 150, 200, $250,300 \mathrm{mg} / \mathrm{L}$ in the form of aqueous solution at the volume of $60 \mathrm{~mL}$. Each variant had five plants per container in triplicate. During the experiment plant height and stem thickness were measured; chlorophyll content and superoxide dismutase (SOD) activity in plants were evaluated. The yield as well as other quantitative traits was recorded at the end, upon harvesting.

Results and Discussion. The analysis of the dynamics of buckwheat plant growth across the experimental variants (Table 1, Fig. 1) shows that with increasing concentration of MET buckwheat height significantly reduced. The maximum effect of preparation MET on lowering buckwheat plant height was observed 20 days after treatment. Then there was a gradual decrease in the MET efficacy.

(C) Jin Xiaomei. 2015.

ISSN 0582-5075. Селекція і насінництво. 2015. Випуск 107. 
Dynamics of reduction in buckwheat stem height across

the experimental variants, \%

\begin{tabular}{|c|c|c|c|c|}
\hline Variant & 7 days & 14 days & 20 days & 43 days \\
\hline $150 \mathrm{mg} / \mathrm{L}$ & 2 & 9 & 15 & 12 \\
\hline $200 \mathrm{mg} / \mathrm{L}$ & 4 & 15 & 19 & 17 \\
\hline $250 \mathrm{mg} / \mathrm{L}$ & 10 & 20 & 25 & 23 \\
\hline $300 \mathrm{mg} / \mathrm{L}$ & 20 & 23 & 30 & 28 \\
\hline
\end{tabular}

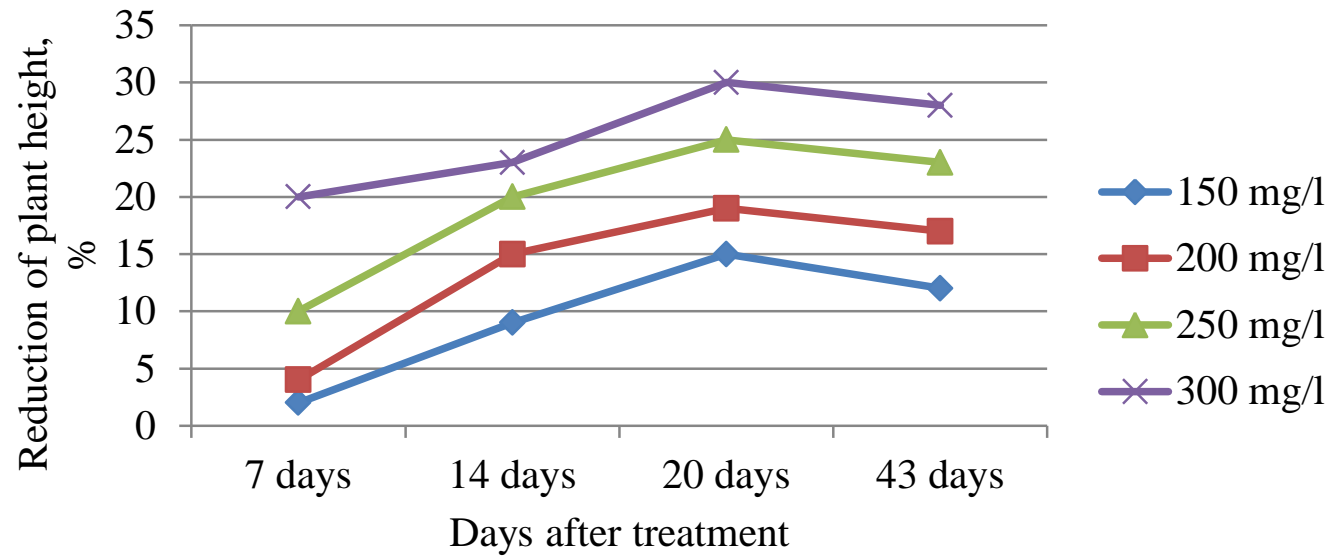

Fig. 1 Dynamics of buckwheat plant height across the experimental variants.

It was experimentally established that with the concentration of MET of $150 \mathrm{mg} / \mathrm{L}$ buckwheat plant height decreased by $12.6 \mathrm{~cm}$, or by $12 \%$ compared to the standard, and the MET concentration of $300 \mathrm{mg} / \mathrm{L}$ reduced plant height by $29.2 \mathrm{~cm}$, or by $28 \%$ compared to the standard.

The analysis of the dynamics of buckwheat stem thickness (Table 2; Fig. 2) across the experimental variants showed that increase in MET caused a rise in buckwheat stem thickness. The maximum stem thickness was achieved on day 20 after treatment. The treatment with MET in the concentration of $150 \mathrm{mg} / \mathrm{L}$ contributed to the increase in buckwheat stem thickness by $0.057 \mathrm{~cm}$, or by $6 \%$ compared to the standard, and the treatment with MET in the concentration of $300 \mathrm{mg} / \mathrm{L}$ provided buckwheat stem thickening by $0.198 \mathrm{~cm}$, or by $27 \%$ compared to the standard.

Table 2

Dynamics of enlargement in buckwheat stem thickness across the experimental variants, cm

\begin{tabular}{|c|c|c|c|c|}
\hline Variant & 7 days & 14 days & 20 days & 43 days \\
\hline $150 \mathrm{mg} / \mathrm{L}$ & 4 & 6 & 8 & 6 \\
\hline $200 \mathrm{mg} / \mathrm{L}$ & 10 & 13 & 15 & 12 \\
\hline $250 \mathrm{mg} / \mathrm{L}$ & 16 & 20 & 23 & 18 \\
\hline $300 \mathrm{mg} / \mathrm{L}$ & 23 & 28 & 32 & 27 \\
\hline
\end{tabular}

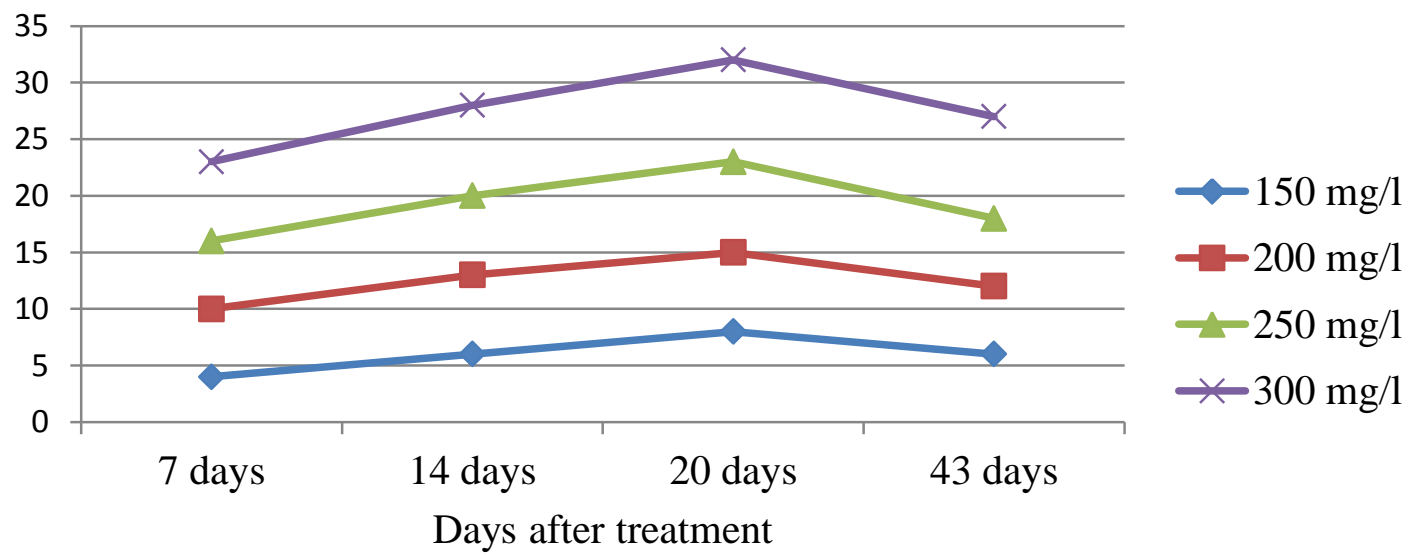

Fig. 2 Dynamics of buckwheat stem thickness across the experimental variants. 
Effect of MET on chlorophyll content at the beginning of the flowering phase. We analyzed chlorophyll content in the third leaf; samples were taken from the middle part of a leaf blade. The analysis of chlorophyll content in buckwheat leaves across the experimental variants showed that chlorophyll content in all the MET-treated variants exceeded the standard value. It was found that chlorophyll content in the variant with the MET concentration of $200 \mathrm{mg} / \mathrm{L}$ on day 10, day 20 and day 30 after treatment was higher by $20.1 \%, 26 \%$ and $17.5 \%$ than the standard, respectively. In the variant with the MET concentration of $250 \mathrm{mg} / \mathrm{L}$ chlorophyll content was slightly inferior to the variant with the concentration of $200 \mathrm{mg} / \mathrm{L}$ (Table 3).

Table 3

Efficacy of different concentrations of met on chlorophyll content in buckwheat leaves, the average for 2 years

\begin{tabular}{|c|c|c|c|c|c|c|}
\hline \multirow{2}{*}{$\begin{array}{c}\text { MET Concen- } \\
\text { tration, mg/L }\end{array}$} & \multicolumn{6}{|c|}{ Chlorophyll Content (mg/g), fresh weight } \\
\cline { 2 - 7 } & $\begin{array}{c}\text { Chlorophyll } \\
\text { Content }\end{array}$ & Gain & $\begin{array}{c}\text { Chlorophyll } \\
\text { Content }\end{array}$ & Gain & $\begin{array}{c}\text { Chlorophyll } \\
\text { Content }\end{array}$ & Gain \\
\hline St & 10.507 & 0 & 5.603 & 0 & 4.712 & 0 \\
\hline 150 & 10.555 & +0.048 & 6.725 & +0.822 & 5.244 & +0.232 \\
\hline 200 & 12.619 & +2.112 & 7.06 & +1.457 & 5.638 & +0.826 \\
\hline 250 & 12.393 & +1.886 & 6.816 & +1.213 & 5.473 & +0.761 \\
\hline 300 & 11.442 & +0.935 & 6.591 & +0.988 & 4.824 & +0.112 \\
\hline
\end{tabular}

Superoxide dismutase (SOD). Our studies revealed influence of the preparation MET on SOD activity in leaves (Table 4). The results showed that superoxide dismutase activity after emergence of inflorescences gradually decreased, regardless of MET treatment. However, its activity slowly dropped upon MET treatment in the concentrations of $200 \mathrm{mg} / \mathrm{L}$ and $250 \mathrm{mg} /$ L. SOD activity in the variant with the MET concentration of $200 \mathrm{mg} / \mathrm{L}$ exceeded the standard on 18.08, 28.08 and 07.09 by $1.97,1.45$ and 1.51 units of activity per fresh weight, respectively.

Table 4

MET Efficacy on SOD Activity in leaves, 2012-2013

\begin{tabular}{|c|c|c|c|}
\hline \multirow{2}{*}{$\begin{array}{c}\text { MET Concen- } \\
\text { tration, mg/L }\end{array}$} & \multicolumn{3}{|c|}{ SOD Activity (units per fresh weight) } \\
\cline { 2 - 4 } & 18.08 & 28.08 & 07.09 \\
\hline $\mathrm{St}$ & 7.46 & 2.10 & 2.04 \\
\hline 150 & 7.85 & 2.22 & 2.10 \\
\hline 200 & 9.43 & 3.55 & 3.55 \\
\hline 250 & 8.87 & 3.42 & 3.37 \\
\hline 300 & 7.35 & 2.30 & 2.03 \\
\hline
\end{tabular}

When analyzing one-plant weight across the variants with various concentrations of MET (150 mg / L, $200 \mathrm{mg} / \mathrm{L}$ and $250 \mathrm{mg} / \mathrm{L}$ ), we found that in all the variants values exceeded the standard ones (Table 5). The yiled in the variant with the concentration of $250 \mathrm{mg} / \mathrm{L}$ was the highest and exceeded the standard by $2.26 \mathrm{~g}$ or by $61.9 \%$, while in the variant with the MET concentration of $300 \mathrm{mg} / \mathrm{L}$ the yield values were below the standard. 1000 grain weight in the variants with the concentrations of $200 \mathrm{mg} / \mathrm{L}$ and $250 \mathrm{mg} / \mathrm{L}$ was higher in comparison with other variants. The grain number per plant was higher than the standard one in the variants with the MET concentration of $150 \mathrm{mg} / \mathrm{L}$ and $200 \mathrm{mg} / \mathrm{L}$, while in other variants it was lower. Grain weight per plant significantly exceeded the standard value only in the variant with the MET concentration of $200 \mathrm{mg} / \mathrm{L}$. In other cases there was no significant difference. 
Influence of Various Concentrations of MET on Buckwheat Performance

\begin{tabular}{|c|c|c|c|}
\hline $\begin{array}{c}\text { MET Concentra- } \\
\text { tion, mg/L }\end{array}$ & $\begin{array}{c}\text { 1000 Grain Weight, } \\
\mathrm{g}\end{array}$ & $\begin{array}{c}\text { Grain Number per } \\
\text { Plant, } \\
\text { pcs. }\end{array}$ & $\begin{array}{c}\text { Grain Weight per } \\
\text { Plant, } \\
\mathrm{g}\end{array}$ \\
\hline $\mathrm{St}$ & 24.5 & 170.5 & 3.65 \\
\hline 150 & 27.2 & 193.6 & 4.29 \\
\hline 200 & 31.0 & 205.6 & 5.91 \\
\hline 250 & 31.7 & 168.5 & 4.73 \\
\hline 300 & 27.3 & 112.4 & 3.30 \\
\hline \multicolumn{3}{|r|}{} & 1.8 \\
\hline
\end{tabular}

Conclusions. The study results showed that buckwheat plants treated with growth stimulator MET had increased lodging-resistance due to a thickened stem and reduced height. Application of MET on buckwheat plants demonstrated efficacy of the concentration of $200 \mathrm{mg} / \mathrm{L}$, when plants were grown only on fertile soil; this approach was ineffective for unfertile soil. MET treatment increased chlorophyll content in the budding phase and improved photosynthetic activity in buckwheat leaves as well SOD effectiveness. As a result, MET treatment increased plant performance and, thus, enhanced yield capacity.

\section{Список використаних джерел}

1. Zhang, Yizhong. Актуальность и перспективность исследования гречихи [Текст] / Yizhong Zhang // Seeds. - 2004. - 23(3). - C. 39-42.

2. Shang, Yulei. Влияние стимулятора роста на замедление старения листьев пшеницы и его урожайности [Текст] / Yulei Shang // Wheat herald. - 2001. - 21(2). - С. 72-75.

3. Zhang, Zheng. Состав белковых комплексных веществ в гречихе и его действие против старения растения [Текст] / Zheng Zhang // Journal of nutrition. - 1999. - 21(2). C. 159-162.

4. Yang, Dewu. The law gained photosynthesis the substance and its fruitfulness is crap / Dewu Yang [Text] // Chinese agricultural science. - 2002. - 35(8). - C. 934-938.

5. Tainer, J. A. Oxygen stress and Superoxide Dismutase [Text] / J. A. Tainer // Plant physiol. 1993. - V. 101, No 1. - P. 7-12.

6. Raychaudhuri, S. S. The role of SOD in combating oxidative stress in higher plants [Text] / S. S. Raychaudhuri, X. W. Deng // Bot. Rev. - 2000. - V. 66, No 1. - P. 89-98.

\section{References}

1. Zhang Yizhong. Actuality and prospect of research on buckwheat. Seeds, 2004; 23(3):39-42.

2. Shang Yulei. The influence of a growth on slowing aging of wheat leaves and yield. Wheat herald, 2001; 21(2):72-75.

3. Zhang Zheng. The protein complex substances in the crap and its effect against aging plants. Journal of nutrition, 1999; 21(2):159-162.

4. Yang Dewu. The law gained photosynthesis the substance and its fruitfulness is crap. Chinese agricultural science, 2002; 35(8):934-938.

5. Tainer JA. Oxygen stress and Superoxide Dismutase. Plant physiol., 1993; 101(1):7-12.

6. Raychaudhuri SS, Deng XW. The role of SOD in combating oxidative stress in higher plants. Bot. Rev., 2000; 66(1):89-98. 
Jin Xiaomei

Ляонінська Академія с.-г. наук, Китайська народна республіка

Гречка як одна із основних круп'яних культур у Китаї має високу харчову цінність завдяки співвідношенню незамінних амінокислот у білку.

Мета і задачі дослідження. Вивчення впливу регулятора росту МЕТ на морфофізіологічні ознаки гречки та їі врожайність. Визначення оптимальної концентрації для досягнення максимального економічного ефекту від застосування МЕT.

Матеріали і методи. Вихідний сорт гречки - районований у КНР Юньчао-5. Досліди було закладено в 2012-2013 pр. на дослідній станції Хэйлунцянської Академії сільськогосподарських наук. Посів проводили у відкритому грунті. Дослід включав п’ять варіантів 3 різною концентрацією МЕТ: 0, 150, 200, 250, 300 мг/л, у вигляді водного розчину об'ємом 60 мл. У кожному варіанті в одній ємності залишали по п'ять рослин у трьох повтореннях. У ході експерименту вимірювали висоту і товщину стебла, вміст хлорофілу і активність супероксиддисмутази (COД, SOD) рослин. Урожай обраховували в кінці при збиранні, як і інші кількісні ознаки.

Обговорення результатів. У ході експерименту вивчено ефективність застосування різних концентрацій МЕТ на деякі морфофізіологічні ознаки гречки. Результати проведених дослідів показали ефективність цього прийому для зниження висоти рослини і збільшення товщини стебла. При концентрації МЕТ 150 мг/л відбувається зменшення висоти гречки на 12,6 см, або 12 \%, а при концентрації 300мг/л зниження росту було 29,2 см або $28 \%$ у порівнянні зі стандартом. Також при підвищенні концентрації МЕТ встановлено позитивний зв'язок з потовщенням стебла, з підвищенням вмісту хлорофілу і зниженням активності СОД. Встановлено найбільш ефективну дію у варіанті з концентрацією МЕТ 200 мг/л. При цьому істотно збільшуються кількість зерна і маса тисячі зерен, а також спостерігається приріст урожаю зерна на 58,9\%.

Висновки. Результати проведених досліджень показали, що рослини гречки, оброблені стимулятором росту МЕТ, мали підвищену стійкість проти вилягання за рахунок потовщення стебла і зниження його висоти. Застосування МЕТ на рослинах гречки свідчить про ефективність прийому в концентрації 200 мг/л лише в умовах вирощування на сприятливих грунтах, для несприятливих грунтів цей прийом не ефективний. Обробка МЕТ підвищує вмісте хлорофілу в лисках у фазі бутонізації і сприяє підвищенню фотосинтетичної діяльності гречки, ефективності СОД. У результаті обробка МЕТ збільшує продуктивність рослини і відповідно підвищується урожайність.

Ключові слова: гречка, МЕТ, хлорофіл, висота рослини, товщина стебла, фізіологія, урожайність

\section{ВЛИЯНИЕ СТИМУЛЯТОРА РОСТА МЕТ НА МОРФОФИЗИОЛОГИЧЕСКИЕ ПРИЗНАКИ ГРЕЧИХИ}

Jin Xiaomei,

Ляонинская Академия с.-х. наук, Китайская народная республика

Гречиха как одна из основных крупяных культур в Китае обладает высокой пищевой ценностью благодаря соотношению незаменимых аминокислот в белке.

Цель и задачи исследований. Изучение влияния регулятора роста МЕT на морфофизиологические признаки гречихи и ее урожайность. Определение оптимальной концентрации для достижения максимального экономического эффекта от применения MET.

Материалы и методы. Исходный сорт гречихи - районированный в КНР Юньчао-5. Опыты были заложены в 2012-2013 гг. на опытной станции Хэйлунцянской Академии сельскохозяйственных наук. Посев проводили в открытом грунте. Опыт включает пять вари- 
антов с различной концентрацией МЕТ: 0, 150, 200, 250, 300 мг/л, в виде водного раствора объемом 60 мл. В каждом варианте в одной емкости оставляли по пять растений в трех повторениях. В ходе эксперимента измеряли высоту и толщину стебля, содержание хлорофилла и активность супероксиддисмутазы (COД, SOD) растений. Урожай учитывался в конце при уборке, как и остальные количественные признаки.

Обсуждение результатов. В ходе эксперимента изучена эффективность применения различных концентраций МЕТ на некоторые морфофизиологические признаки гречихи. Результаты проведенных опытов показали эффективность этого приема для снижения высоты растения и увеличения толщины стебля. При концентрации МЕТ 150 мг/л происходит снижение роста гречихи на 12,6 см, или $12 \%$ по сравнению со стандартом, а при концентрации 300мг/л снижение роста было 29,2 см или 28 \% по сравнению со стандартом. Также при повышении концентрации МЕТ обнаружена положительная связь с утолщением стебля, с повышением содержания хлорофилла и снижением активности СОД. Установлено, что наиболее эффективное действие обнаруживается в варианте с концентрацией МЕТ 200 мг/л. При этом существенно увеличиваются количество зерна и вес тысячи зерен, а также наблюдается прирост урожая зерна на 58,9 \%.

Выводы. Результаты проведенных исследований показали, что растения гречихи, обработанные стимулятором роста МЕТ, имели повышенную устойчивость к полеганию за счет утолщения стебля и снижения его высоты. Применение MET на растениях гречихи свидетельствует об эффективности приема в концентрации 200 мг/л только в условиях роста на благоприятных почвах, для неблагоприятных почв этот прием не эффективен. Обработка МЕТ повышает содержание хлорофилла в листьях в фазе бутонизации и способствует повышению фотосинтетической деятельности гречихи, эффективности СОД. В результате обработка МЕТ увеличивает продуктивность растения и соответственно повышается урожайность.

Ключевье слова: гречиха, МЕТ, хлорофилл, высота растения, толщина стебля, физиология, урожайность

\section{INFLUENCE OF GROWTH STIMULATOR MET ON MORPHO-PHYSIOLOGICAL TRAITS OF BUCKWHEAT}

Jin Xiaomei,

Liaoning Academy of Agricultural Sciences, Chinese People's Republic

Buckwheat as one of the major cereals in China has a high nutritional value due to the balance of essential amino acids in protein.

The aim and tasks of the study. Investigation of effects of the growth regulator MET on buckwheat morpho-physiological traits and yield capacity. Determination of an optimum concentration to achieve the maximum economic benefit from application of MET.

Material and methods. The test buckwheat variety - released in China variety Yunchao-5. The experiments were laid out in 2012-2013 at the Experimental Station of Heilongiiang Academy of Agricultural Sciences.

Planting was carried out in open ground. Experience has five options with various concentrations MET: $0,150,200,250,300 \mathrm{mg} / \mathrm{L}$, an aqueous solution volume of $60 \mathrm{ml}$. The experiment included five variants with various concentrations of MET: 0, 150, 200, 250, $300 \mathrm{mg} / \mathrm{L}$ in the form of aqueous solution at the volume of $60 \mathrm{~mL}$. Each variant had five plants per container in triplicate. During the experiment plant height and stem thickness were measured; chlorophyll content and superoxide dismutase (SOD) activity in plants were evaluated. The yield as well as other quantitative traits was recorded at the end, upon harvesting.

Results and Discussion. The efficacy of various concentrations of MET on some buckwheat morpho-physiological traits was experimentally studied. The results of these experiments 
demonstrated the efficacy of MET to reduce plant height and to increase stem thickness. When MET being applied at the concentration of $150 \mathrm{mg} / \mathrm{L}$, buckwheat height decreased by 12.6 $\mathrm{cm}$, or by $12 \%$ compared to the standard, the concentration of $300 \mathrm{mg} / \mathrm{L}$ caused the reduction in height by $29.2 \mathrm{~cm}$, or by $28 \%$ compared to the standard. In addition, there were positive correlations between increasing concentrations of MET and stem thickening, between increasing concentrations of MET and rise in chlorophyll content, and between increasing concentrations of MET and decline in SOD activity. It was found that the MET concentration of $200 \mathrm{mg}$ / L was the most effective. In the variant with this concentration the grain amount and 1000 grain weight significantly increased; the gain in grain yield by $58.9 \%$ was also observed.

Conclusions. The study results showed that buckwheat plants treated with growth stimulator MET had increased lodging-resistance due to a thickened stem and reduced height. Application of MET on buckwheat plants demonstrated efficacy of the concentration of $200 \mathrm{mg} / \mathrm{L}$, when plants were grown only on fertile soil; this approach was ineffective for unfertile soil. MET treatment increased chlorophyll content in the budding phase and improved photosynthetic activity in buckwheat leaves as well SOD effectiveness. As a result, MET treatment increased plant performance and, thus, enhanced yield capacity.

Key words: buckwheat, MET, chlorophyll, plant height, stem thickness, physiology, yield capacity 